\title{
Pyrolysis Characteristics and Kinetics of Phoenix Tree Residues as a Potential Energy
}

DOI: $10.15255 / K U I .2015 .028$

KUI-28/2015

Original scientific paper Received May 25, 2015 Accepted July 15, 2015

\author{
H. Li, ${ }^{*}$ X.-H. Li, L. Liu, K.-Q. Li, and X.-H. Wang \\ Nanjing Agricultural University, 210031 Nanjing, P.R. China
}

\begin{abstract}
$\|$ Abstract
By using a thermogravimetric analyser under argon atmosphere, the pyrolysis process and the kinetic model of phoenix tree residues (the little stem, middle stem, and leaf) at a $30^{\circ} \mathrm{C} \mathrm{min}^{-1}$ heating rate and the phoenix tree mix at three different heating rates $\left(10^{\circ} \mathrm{C} \mathrm{min}^{-1}, 30^{\circ} \mathrm{C} \mathrm{min}^{-1}\right.$, and $\left.50{ }^{\circ} \mathrm{C} \mathrm{min}^{-1}\right)$ were examined. The catalyst and the co-pyrolysis samples were at a $30^{\circ} \mathrm{C} \mathrm{min}^{-1}$ heating rate. The catalysts were $\mathrm{Na}_{2} \mathrm{CO}_{3}, \mathrm{ZnCl}_{2}$ and $\mathrm{CaO}$ in a mass fraction of $5 \%$. The experimental results revealed that the phoenix tree residues pyrolysis process consisted of three stages: dehydration stage, main pyrolysis stage, and the slow decomposition of residues. As the heating rate increased, the pyrolysis characteristic temperature of the phoenix tree grew, there was a backward-shift of the pyrolysis rate curve, and the mass loss rate gradually increased. The phoenix tree residues' activation energy changed throughout the whole pyrolysis process, and the pyrolysis temperature ranges of the three main components (cellulose, hemicellulose, and lignin) existed in overlapping phenomenon. As compared to the little stem, middle stem, and leaf, the phoenix tree mix was more likely to be pyrolysed under the same heating rate. Different catalysts had a different impact on the pyrolysis: $\mathrm{ZnCl}_{2}$ moved the start point of the reaction to the lower temperatures, but did not speed up the reaction; $\mathrm{Na}_{2} \mathrm{CO}_{3}$ speeded up the reaction without changing the start point of the reaction; $\mathrm{CaO}$ speeded up the reaction, moved the start point of the reaction to higher temperatures.
\end{abstract}

\section{\| Keywords}

Phoenix tree residues, pyrolysis, thermogravimetric analysis, kinetics, catalysts

\section{Introduction}

Biomass energy is a kind of chemical energy that is stored in biomass, which is transferred from light energy by photosynthesis. As an ideal renewable energy, bioenergy consumption ranks fourth worldwide in the most consumed sources of energy (about $14 \%$ of the total consumption) and ranks just behind fossil oil, natural gas, and coal. ${ }^{1}$ Indeed, biomass has been predicted to account for up to $40 \%$ of the world's energy consumption by the year 2020 . In fact, plant yield alone is already 20 times that of mineral energy, ${ }^{2}$ which is indicative of the abundant reserves of biomass energy. Furthermore, the classic energy consumptions have costly disadvantages: namely, the negative impact of global warming caused by greenhouse gases, the energy crisis of non-renewable fossil energy, external dependence, security coefficients of energy supply, and so on. Therefore, reasonable utilization of biomass energy is of great interest to the world.

Biomass pyrolysis has been shown to be a novel, effective biomass-energy utilization technique. ${ }^{3-7}$ The technique is not only applicable to the combustion and gasifying process of biomass but also to the transfer of biomass into gas, liquid, and solid forms of high energy density. Generally, biomass pyrolysis is a process in which gas (biomass gas),

\footnotetext{
* Corresponding author: Dr. Hua Li

e-mail: lihua@njau.edu.cn
}

liquid (bio-oil), and solid (biochar) $)^{8}$ are gained as products from the biomass through thermal degradation under oxygen-free or limited oxygen conditions. This process consists of very complex physical chemical reactions, so a kinetics analysis, focusing on the mechanisms underlying the physical changes and chemical reactions (especially in heterogeneous and non-isotherm cases), is highly important for understanding biomass pyrolysis. ${ }^{9-12}$

Recently, many researchers have achieved significant progress in the pyrolysis of tree biomass. For example, Changqing Dong et al. ${ }^{13}$ studied the influence of different chemical components in pine and cottonwood on the distribution of products in rapid pyrolysis. Additionally, Yaping $\mathrm{GaO}^{14}$ analysed three factors (atmosphere, heating rate, and air velocity) in the pyrolysis of four different pines: namely, white pine, yellow pine, Chinese pine, and camphor. Furthermore, Yanfen Liao et al. ${ }^{15}$ studied the pyrolysis and combustion of different kinds of barks, branches, leaves, stalks, sugarcane residues, and sugarcane leaves. However, some rare research has been conducted on the pyrolysis of the common and classic phoenix tree residues in Nanjing Area, including the little stem, middle stem, leaf, and leaf branch mix (named the phoenix tree mix). This paper presents the research based on the characteristics of the phoenix tree mix pyrolysis at different heating rates and with different catalysts by using a thermogravimetric analyser. After further calculation, a kinetics model divided into different periods based upon the pyrolysis process is obtained. 


\section{Experimental}

\section{Experimental samples}

The phoenix tree residues (the little stem, middle stem, leaf, and tree mix) in the Nanjing Area were chosen as the experimental samples. Every sample was ground to $830 \mu \mathrm{m}-1500 \mu \mathrm{m}$ size particles, dried for $24 \mathrm{~h}$ under $105{ }^{\circ} \mathrm{C}$, and then stored in a drying vessel.

\section{Experimental conditions}

A simultaneous thermal analyser STA449F3 produced by the German Netzsch Company was the instrument used in this study. High-purity argon gas was used as a protection gas with a flow of $10 \mathrm{ml} \mathrm{min}^{-1}$, and the heating rates were $10{ }^{\circ} \mathrm{C} \mathrm{min}^{-1}, 30^{\circ} \mathrm{C} \mathrm{min}^{-1}$, and $50{ }^{\circ} \mathrm{C} \mathrm{min}^{-1}$ in the pyrolysis of the tree mix, and $30^{\circ} \mathrm{C} \mathrm{min}^{-1}$ in the other samples. In all the experiments, the final temperature was $900^{\circ} \mathrm{C}$. The catalysts were $\mathrm{Na}_{2} \mathrm{CO}_{3}, \mathrm{ZnCl}_{2}$, and $\mathrm{CaO}$ in the mass fraction of $5 \%$.

\section{Results and discussion}

\section{The pyrolysis process of the phoenix tree residues}

Fig. 1 illustrates the thermogravimetric (TG) curves as well as the differential thermogravimetric (DTG) curves of the pyrolysis process of the phoenix little stem, middle stem, leaf, and tree mix at a heating rate of $30{ }^{\circ} \mathrm{C} \mathrm{min}^{-1}$.
As temperature increased, the samples' major components (such as cellulose, hemicellulose, and lignin) produced gases under a series of chemical reactions, and the TG-DTG curves revealed the distribution of gas and solid pyrolysis products. As determined from the samples' pyrolysis experiences, pyrolysis consisted of three distinct stages: the dehydration stage (stage I), the main pyrolysis stage (stage II), and the slow decomposition of residues (stage III). In the first stage, the room temperature range was $165-200{ }^{\circ} \mathrm{C}$, and the TG curves had a small mass loss. Furthermore, the DTG mass loss rate exhibited only little changes because of the moisture evaporation in the samples. The little stems' water loss peaks showed up at $120{ }^{\circ} \mathrm{C}$, and other samples showed up slightly earlier, at $110{ }^{\circ} \mathrm{C}$. Stage II, ending at $505-550{ }^{\circ} \mathrm{C}$, was the major stage in the pyrolysis process, where the samples decomposed and different volatiles spread out by heating under an anoxia atmosphere. Also in this stage, up to $60-70 \%$ of the samples' mass loss occurred with rapidly decreasing TG curves and evident peaks in the DTG curves. More precisely, the peaks for the little and middle stem are shown at $365^{\circ} \mathrm{C}$, and the rest show at $350{ }^{\circ} \mathrm{C}$. These are the results from the complete reactions of three components in the samples. ${ }^{16}$ In the final stage, stage III, the samples formed loose porous carbon because of the diffusing volatiles, so this stage can also be called the carbonization stage. Both TG and DTG curves changed slowly as caused by lignin decomposition ${ }^{17}$ and the long duration of carbonization.
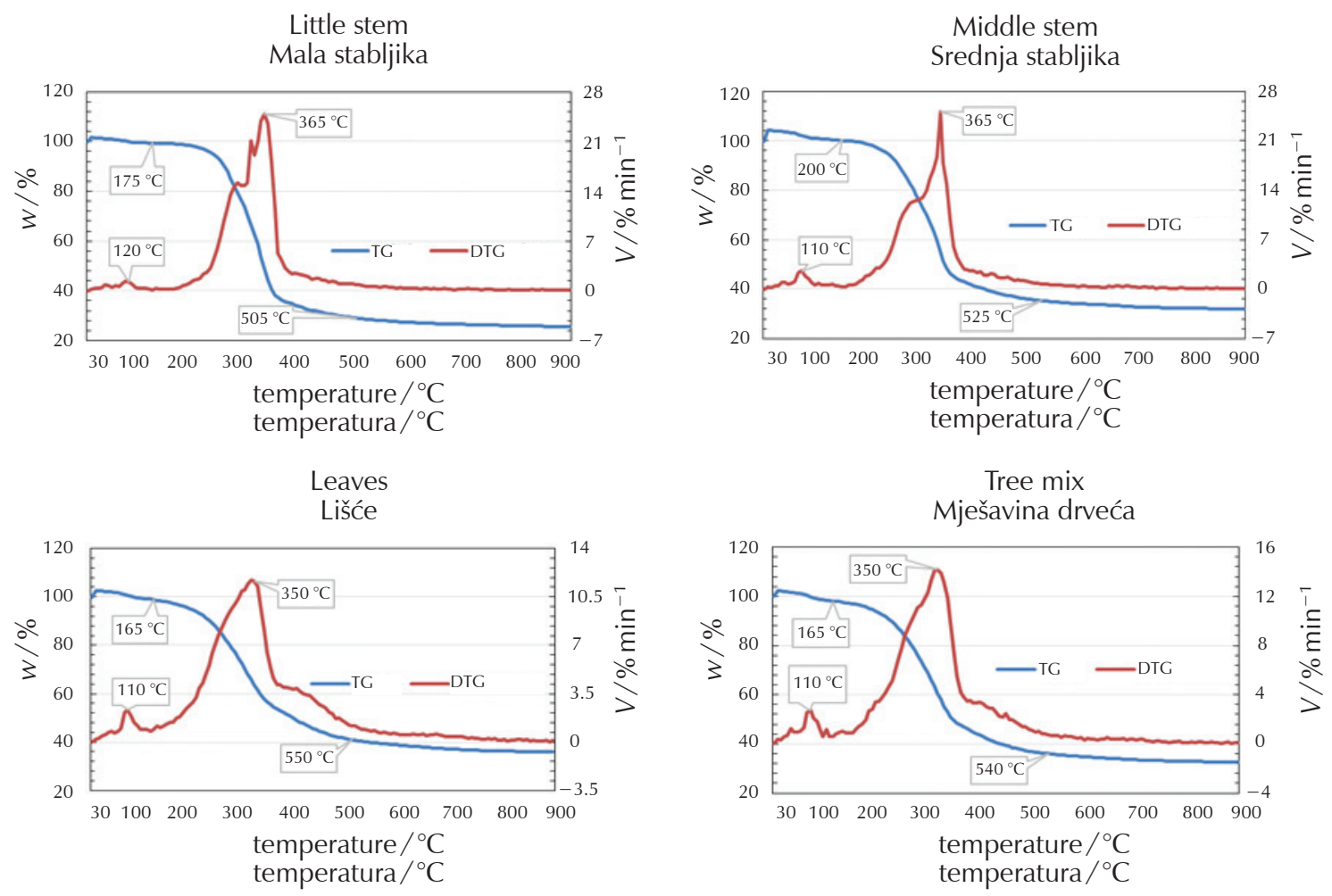

Fig. 1 - TG and DTG curves of phoenix tree residues pyrolysis at a heating rate of $30{ }^{\circ} \mathrm{C} \mathrm{min}^{-1}$ Slika 1 - TG- i DTG-krivulje pirolize ostataka stabla feniks pri brzini zagrijavanja $30{ }^{\circ} \mathrm{C} \mathrm{min}^{-1}$ 


\section{Impact of the heating rate on the pyrolysis}

The heating rate is one of the most important factors in biomass pyrolysis, particularly as it can influence the pyrolysis rate in a different temperature region, in products distribution, or in the biomass stay time. Fig. 2 shows the DTG curves of the tree mix under three different heating rates.

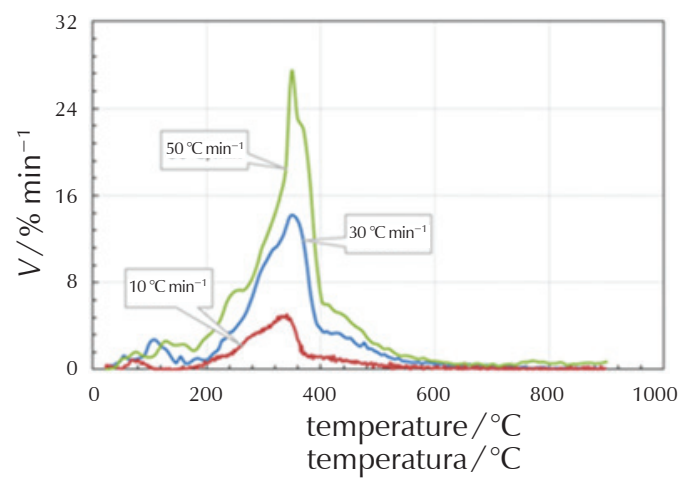

Fig. 2 - DTG curves of the tree mix under different heating rates Slika 2 - DTG-krivulje drvne smjese pri različitim brzinama zagrijavanja

The relative characteristic pyrolysis temperatures of the samples are summarized in Table 1. For the water evaporation rate peaks of the DTG curves in stage I, the maximum dehydrate rate is marked as $V_{1}$, and the related peak temperature is $T_{1}$. As for the mass loss rate peaks in stage II, the maximum mass loss rate is called $V_{2}$ and the related peak temperature is $T_{2}$.

As seen in Table 1 and Fig. 2, as the heating rate increases, all the characteristic temperatures $T$ of the tree mix pyrolysis grow with the backward move of the pyrolysis rate curves. This indicates that the higher the heating rate, the stronger the influence of diffusion on the temperature gradients, thus leading to heating transfer lag and increased $T$ values. In addition, the amount the $T$ value increases becomes lower at the higher heating rates. For example, the $T_{2}$ values at $30{ }^{\circ} \mathrm{C} \mathrm{min}-1$ and $50{ }^{\circ} \mathrm{C} \mathrm{min}-1$ are the same, which reveals lower impact of an increasing heating rate on the heating transfer lag.

Fig. 3 shows heating rate's influence on the mass loss rate. It can be seen that the mass loss rate $V$ gradually accelerates under the higher heating rates, and $V_{2}$ changes more easily than does $V_{1}$. Normally, higher heating rates allow the biomass to proceed through pyrolysis under a higher temperature, thus resulting in an accelerated pyrolysis.

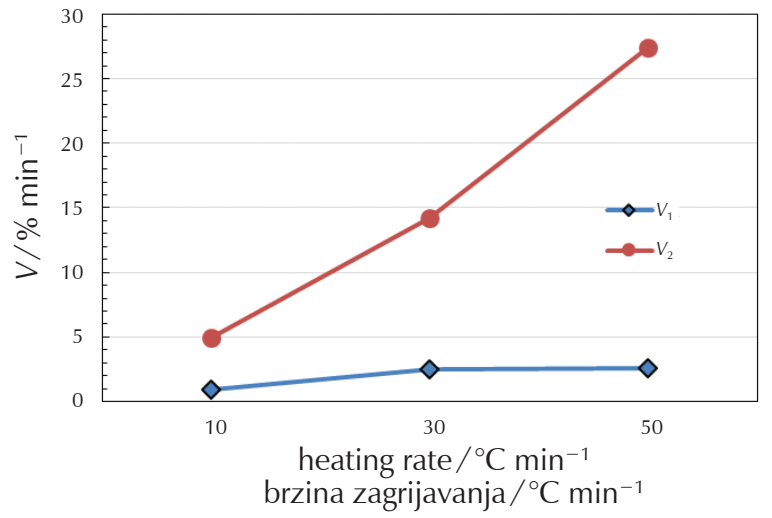

Fig. 3 - Influence of the heating rate on the tree mix mass loss rate. $V_{1}$ is the maximum dehydrate, $V_{2}$ is the maximum mass loss rate.

Slika 3 - Utjecaj brzine zagrijavanja na brzinu gubitka mase drvne smjese. $V_{1}-$ maksimum dehidratiranja, $V_{2}-$ maksimalna brzina gubitka mase.

\section{Impact of the different catalysts on the pyrolysis}

Catalysts can move the start point of the pyrolysis to the low temperature direction, or speed up the reaction, thus improve the efficiency of the pyrolysis. Different catalysts have a different impact on the pyrolysis, and also has different catalytic efficiency. ${ }^{18-21}$ Three different kinds of catalyst were chosen in this paper: they are carbonate $\mathrm{Na}_{2} \mathrm{CO}_{3}$, alkaline metallic oxide $\mathrm{CaO}$, and chlorine salt $\mathrm{ZnCl}_{2}$. Fig. 4 shows the DTG curves with different catalysts at the heating rate of $30{ }^{\circ} \mathrm{C} \mathrm{min}^{-1}$.

Table 1 - Maximum dehydration rate temperature $T_{1}$ and the maximum mass loss rate temperature $T_{2}$ of tree mix under different heating rates $\left({ }^{\circ} \mathrm{C}\right)$

Tablica 1 - Maksimalna temperatura brzine dehidratiranja $T_{1}$ i maksimalna temperatura brzine gubitka mase $T_{2}$ drvne smjese pri različitima brzinama zagrijavanja $\left({ }^{\circ} \mathrm{C}\right)$

\begin{tabular}{c|r|r|r}
\hline $\begin{array}{l}\text { Heating rate } /{ }^{\circ} \mathrm{C} \min ^{-1} \\
\text { Brzina zagrijavanja } /{ }^{\circ} \mathrm{C} \mathrm{min}^{-1}\end{array}$ & 10 & 30 & 50 \\
\hline$T_{1} /{ }^{\circ} \mathrm{C}$ & 80 & 110 & 125 \\
$T_{2} /{ }^{\circ} \mathrm{C}$ & 340 & 350 & 350 \\
\hline
\end{tabular}




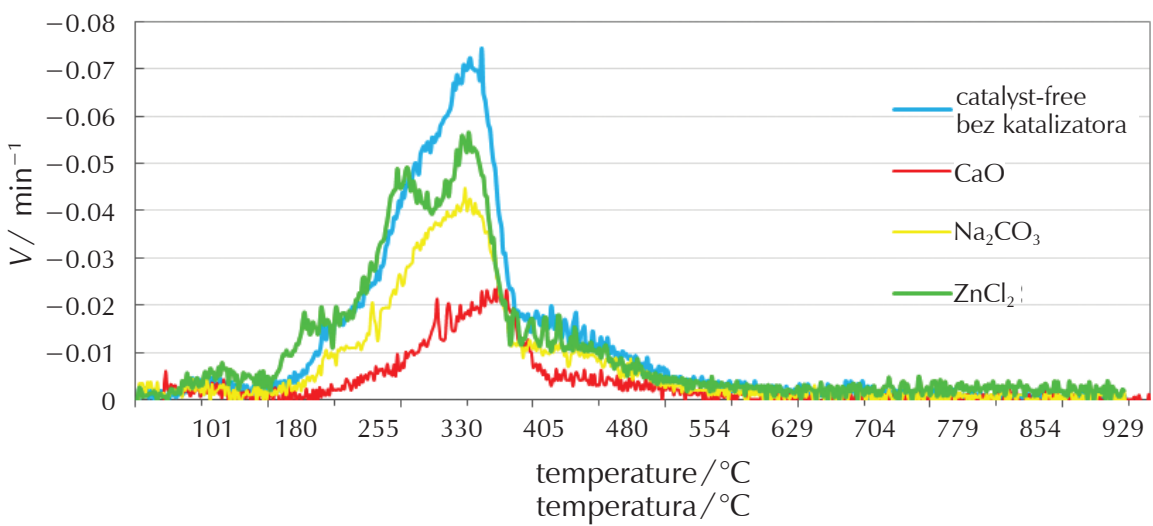

Fig. 4 - The DTG curves with different catalyst at the heating rate of $30{ }^{\circ} \mathrm{C} \mathrm{min}^{-1}$

Slika 4 - DTG-krivulje s različitim katalizatorima pri brzini zagrijavanja od $30{ }^{\circ} \mathrm{C} \mathrm{min}-1$

As shown in Fig. 4, when contrasted to the phoenix tree mix pyrolysed at the heating rate of $30{ }^{\circ} \mathrm{C} \mathrm{min}^{-1}, \mathrm{ZnCl}_{2}$ moves the start point of the reaction to the lower temperatures, but does not speed up the reaction; $\mathrm{Na}_{2} \mathrm{CO}_{3}$ speeds up the reaction without changing the start point of the reaction; $\mathrm{CaO}$ speeds up the reaction, but it moves the start point of the reaction to the higher temperatures.

\section{Kinetics analysis of phoenix tree residue pyrolysis}

The mass loss ratio of samples can be expressed by the Arrhenius kinetics equation:

$$
\frac{\mathrm{d} x}{\mathrm{~d} t}=k_{0} \exp \left[-\frac{E}{R T}\right] f(x)
$$

Conversion $x$ at $t$ moment is:

$$
x=\frac{m_{\mathrm{o}}-m(t)}{m_{\mathrm{o}}-m_{\mathrm{f}}}
$$

In this equation, $m_{\mathrm{o}}$ is the initial mass of samples, $m_{\mathrm{f}}$ is the mass of samples after pyrolysis, $m(t)$ is the sample mass at moment $t, k_{\mathrm{o}}$ is the pre-exponential factor, $E$ is the apparent activation energy, $R$ is the gas constant $\left(8.314 \mathrm{~J} \mathrm{~mol}^{-1} \mathrm{~K}^{-1}\right)$, $T$ is the absolute temperature, and $f(x)$ is the solid conversion function model relying on the reaction mechanism and types. ${ }^{22,23} E, k_{0}$, and $f(x)$ are called the kinetic triplet, and the driving goal behind studying kinetics is determining the kinetic triplet.

After replacing Eq. (1) with the heating rate $q=\mathrm{d} T / \mathrm{d} t\left(\mathrm{Ks}^{-1}\right)$ and $f(x)$, which can be expressed by the most simplistic first order mechanism reaction equation $f(x)=1-x$, it can be obtained that:

$$
\frac{\mathrm{d} x}{\mathrm{~d} T}=\frac{k_{0}}{q} \exp \left[-\frac{E}{R T}\right](1-x)
$$

Integrate Eq. (3), and obtain:

$$
\int_{0}^{x} \frac{d x}{1-x}=\frac{k_{0}}{q} \int_{T_{0}}^{T} \exp \left(-\frac{E}{R T}\right) \mathrm{d} T
$$

The right side of the equation above can only produce an approximate solution, not an analytical solution.

In this paper, the Agrawal-Sivasuburamanian integration methods ${ }^{24}$ one of the most effective methods for the precise evaluation of temperature, is applied to evaluate the above equation. The result is:

$$
\ln \left(-\frac{\ln (1-x)}{T^{2}}\right)=\ln \left(\frac{k_{0}}{q} \frac{R}{E} \frac{1-2 \frac{R T}{E}}{1-5\left(\frac{R T}{E}\right)^{2}}\right)-\frac{E}{R T}
$$

where $<<1$, so Eq. (5) can be simplified as:

$$
\ln \left(-\frac{\ln (1-x)}{T^{2}}\right)=\ln \left(\frac{k_{0}}{q} \frac{R}{E}\right)-\frac{E}{R T}
$$

The $\ln \left(-\frac{\ln (1-x)}{T^{2}}\right) \sim \frac{1}{T}$ curve can be drawn according to the pyrolysis data, and both the apparent activation energy $E$ and pre-exponential factor $k_{0}$ can be solved by the straight slope and intercept.

The kinetics parameters of the phoenix tree residues pyrolysis at different stages as deduced by the above mentioned methods are summarized in Table 2. Although this kinetics analysis is divided into several parts based upon the three stages of pyrolysis, it is still hard to describe the whole pyrolysis process, particularly due to the changing activation energy and the overlapping temperature ranges of the three components pyrolysis. In addition, in comparison to other samples, the tree mix has a relatively smaller activation energy and pre-exponential factor at the same heating rate of $30{ }^{\circ} \mathrm{C} \mathrm{min}^{-1}$, which allows for an easier pyrolysis of the tree mix. 
Table 2 - Kinetics parameters of the phoenix tree residues pyrolysis at different stages

Tablica 2 - Kinetički parametri pirolize ostataka stabla feniks u različitim fazama

\begin{tabular}{|c|c|c|c|c|c|c|c|}
\hline \multirow{2}{*}{\multicolumn{2}{|c|}{$\begin{array}{l}\text { Material } \\
\text { Materijal } \\
\text { Heating rate } /{ }^{\circ} \mathrm{C} \min ^{-1} \\
\text { Brzina zagrijavanja } /{ }^{\circ} \mathrm{C} \min ^{-1}\end{array}$}} & $\begin{array}{l}\text { Leaves } \\
\text { Lišće }\end{array}$ & $\begin{array}{l}\text { Little stem } \\
\text { Mala stabljika }\end{array}$ & $\begin{array}{l}\text { Middle stem } \\
\text { Srednja } \\
\text { stabliika }\end{array}$ & \multicolumn{3}{|c|}{$\begin{array}{c}\text { Tree mix } \\
\text { Drvna smjesa }\end{array}$} \\
\hline & & \multicolumn{3}{|c|}{30} & 10 & 30 & 50 \\
\hline \multirow{3}{*}{$\begin{array}{l}\text { stage I } \\
\text { faza I }\end{array}$} & $E / \mathrm{kJ} \mathrm{mol}^{-1}$ & 59.52 & 32.77 & 139.17 & 152.00 & 33.28 & 20.05 \\
\hline & $k_{\mathrm{o}} / \mathrm{s}^{-1}$ & $4.11 \cdot 10^{5}$ & $1.37 \cdot 10^{2}$ & $1.46 \cdot 10^{13}$ & $1.31 \cdot 101^{5}$ & $1.46 \cdot 10^{2}$ & 4.72 \\
\hline & $r^{2}$ & 0.9799 & 0.8953 & 0.9877 & 0.9701 & 0.9346 & 0.9347 \\
\hline \multirow{3}{*}{$\begin{array}{l}\text { stage II } \\
\text { faza II }\end{array}$} & $E / \mathrm{kJ} \mathrm{mol}^{-1}$ & 43.08 & 93.56 & 48.20 & 59.96 & 52.58 & 61.33 \\
\hline & $k_{\mathrm{o}} / \mathrm{s}^{-1}$ & $1.48 \cdot 10^{2}$ & $7.11 \cdot 10^{6}$ & $4.83 \cdot 10^{2}$ & $8.26 \cdot 10^{3}$ & $1.16 \cdot 10^{3}$ & $6.30 \cdot 10^{3}$ \\
\hline & $r^{2}$ & 0.9329 & 0.9684 & 0.899 & 0.9334 & 0.9268 & 0.9105 \\
\hline \multirow{3}{*}{$\begin{array}{l}\text { stage III } \\
\text { faza III }\end{array}$} & $E / \mathrm{kJ} \mathrm{mol}^{-1}$ & 57.06 & 27.13 & 49.64 & 30.01 & 36.63 & 36.71 \\
\hline & $k_{\mathrm{o}} / \mathrm{s}^{-1}$ & 44.4 & $9.22 \cdot 10^{-1}$ & 17.6 & 1.11 & 3.18 & 2.02 \\
\hline & $r^{2}$ & 0.9462 & 0.8903 & 0.946 & 0.8553 & 0.9657 & 0.8674 \\
\hline
\end{tabular}

$E$ is apparent activation energy, $k_{0}$ is pre-exponential factor, $r^{2}$ is correlation coefficient.

$E$ je prividna energija aktivacije, $k_{\mathrm{o}}$ predeksponencijalni faktor, $r^{2}$ je korelacijski koeficijent.

The kinetics parameters of the phoenix tree residues pyrolysis with different catalysts at the main pyrolysis stage as deduced by the above mentioned methods are summarized in Table 3. According to the activation energy $E$ and pre-exponential factor $k_{\mathrm{o}}$ at the same heating rate, compared with these parameters of free-catalyst, $\mathrm{ZnCl}_{2}$ moves the start point of the reaction to the lower temperatures, $\mathrm{Na}_{2} \mathrm{CO}_{3}$ does not change the start point of the reaction, $\mathrm{CaO}$ moves the start point of the reaction to the higher temperatures.

Table 3 - Kinetics parameters of the phoenix tree residues pyrolysis with different catalysts at the heating rate of $30{ }^{\circ} \mathrm{C} \min ^{-1}$

Tablica 3 - Kinetički parametri pirolize ostataka stabla feniks s različitim katalizatorima pri brzini zagrijavanja od $30{ }^{\circ} \mathrm{C} \min ^{-1}$

\begin{tabular}{c|c|c|c|c}
\hline $\begin{array}{l}\text { Catalyst } \\
\text { Katalizator }\end{array}$ & $\begin{array}{c}\text { Catalyst free } \\
\text { Bez } \\
\text { katalizatora }\end{array}$ & $\mathrm{ZnCl}_{2}$ & $\mathrm{CaO}$ & $\mathrm{Na}_{2} \mathrm{CO}_{3}$ \\
\hline$E / \mathrm{KJ} \mathrm{mol}^{-1}$ & 113.9018 & 91.454 & 136.3496 & 100.5994 \\
$k_{\mathrm{o}} / \mathrm{s}^{-1}$ & $\begin{array}{c}3.34263 \\
10^{-6}\end{array}$ & $\begin{array}{c}3.22283 \\
\cdot 10^{-6}\end{array}$ & $\begin{array}{c}9.50335 \\
10^{-6}\end{array}$ & $\begin{array}{c}4.47081 \\
r^{2}\end{array}$ \\
\hline
\end{tabular}

$E$ is apparent activation energy, $k_{0}$ is pre-exponential factor, $r^{2}$ is correlation coefficient.

$E$ je prividna energija aktivacije, $k_{\mathrm{o}}$ predeksponencijalni faktor, $r^{2}$ je korelacijski koeficijent.

\section{Conclusions}

Throughout this study, a number of conclusions were established; they are as follows:

1) The phoenix tree residues pyrolysis process consists of three separate stages: the dehydration stage, the main pyrolysis stage, and the slow decomposition of residues. In the main pyrolysis stage, the competition reactions of cellulose, hemicellulose, and lignin occurs, and the mass loss ratio rises to $60-70 \%$.

2) As the heating rate increases, the characteristic temperature of the tree mix pyrolysis grows higher, the weight loss rate accelerates, and the pyrolysis rate curves move backwards. However, with these higher heating rates, the increasing amount of the characteristic temperature becomes smaller.

3) According to the curves and parameters of pyrolysis, different catalysts have different impact on the pyrolysis: $\mathrm{ZnCl}_{2}$ moves the start point of the reaction to the lower temperatures, but does not speed up the reaction; $\mathrm{Na}_{2} \mathrm{CO}_{3}$ speeds up the reaction without changing the start point of the reaction; $\mathrm{CaO}$ speeds up the reaction, it moves the start point of the reaction to the higher temperatures.

4) The activation energy of the phoenix residues pyrolysis changes in the whole stages, and the pyrolysis temperature ranges of the three main components (cellulose, 
hemicellulose, and lignin) exist in overlapping phenomenon.

5) As compared to the little stem, middle stem, and leaves, the tree mix is more likely to be pyrolysed at the same heating rate, partly due to its relatively smaller activation energy and pre-exponential factor.

\section{List of abbreviations and symbols Popis kratica i simbola}

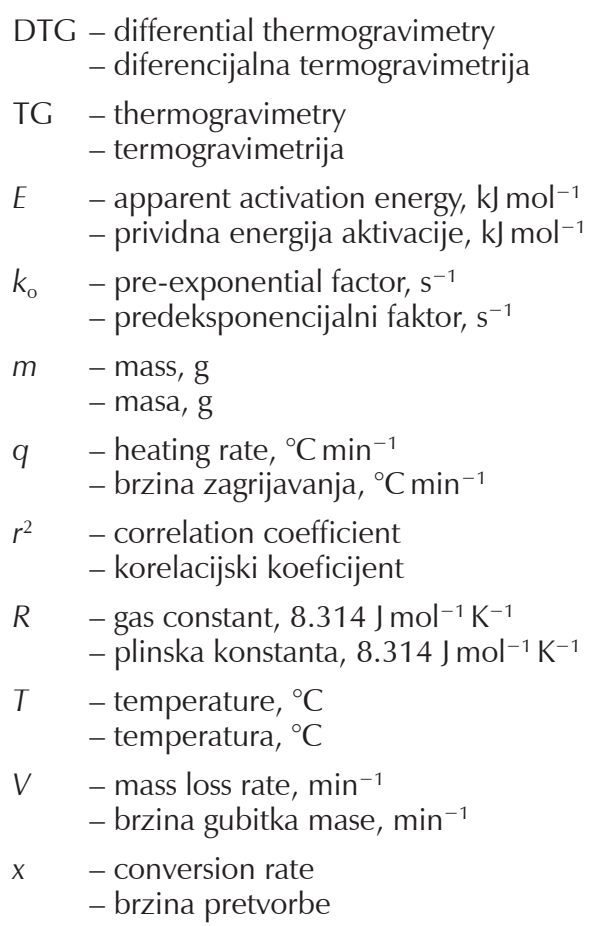

\section{References \\ Literatura}

1. R. C. Saxena, D. K. Adhikari, Biomass-based energy fuel through biochemical routes: a reviews, Renew. Sust. Energ. Rev. 13 (1) (2009) 156-167, doi: http://dx.doi. org/10.1016/j.rser.2007.07.011.

2. T. Lv, Y.-G. Liu, The work characteristics of biomass power plant, Guide of Sci-tech Magazine 29 (2012) 399-402 (in Chinese).

3. B. V. Babu, A. S. Chaurasia, Modeling simulation and estimation of optimum parameters in pyrolysis of biomass, Energ. Convers. Manag. 44 (2003) 2135-2158, doi: http://dx.doi.org/10.1016/S0196-8904(02)00237-6.

4. K. M. Bryden, J. Haggem, Modeling the combined impact of moisture and char shrink age on the pyrolysis of a biomass particle, Fuel 82 (2003) 1633-1644, doi: http://
dx.doi.org/10.1016/S0016-2361(03)00108-X.

5. B. V. Babu, A. S. Chaurasia, Modeling for pyrolysis of solid particle kinetics and heat transfer effects, Energ. Convers. Manag. 44 (2003) 2251-2275, doi: http://dx.doi. org/10.1016/S0196-8904(02)00252-2.

6. T. Sharma, R. T. Rajeswara, Kinetics of pyrolysis of rice husk, Biores. Technol. 67 (1) (1999) 53-59, doi: http:// dx.doi.org/10.1016/S0960-8524(99)00073-5.

7. J. Wang, The fundamental research of preparing liquid fuel based on microwave pyrolysis of biomass, Huai Nan: Anhui University of Science and Technology, 2007 (in Chinese).

8. L. Shen, L.-T. Liu, Z.-Jun Yao, G. Liu, M. Lucas, Development Potentials and Policy Options of Biomass in China, Environ. Manag. 46 (2010)539-554, doi: http://dx.doi. org/10.1007/s00267-010-9476-4.

9. K. Raveendran, A. Ganesh, K. C. Khilar, Pyrolysis characteristics of biomass and biomass components, Fuel 75 (8) (1996) 987-998, doi: http://dx.doi.org/10.1016/00162361(96)00030-0.

10. M. J. G. Alonso, D. Alvarez, A. G. Borrego, Systematic effects of coal rank and type on the kinetics of coal pyrolysis, Energ. Fuel. 15 (2) (2001) 413-428, doi: http://dx.doi. org/10.1021/ef000170x

11. K Miura, A new and simple method to estimate $f(E)$ and $k_{0}(E)$ in the distributed activation energy model from three sets of experimental data, Energ. Fuel. 9 (1995) 302-307, doi: http://dx.doi.org/10.1021/ef00050a014.

12. A. Sharma, T. R. Rao, Kinetics of pyrolysis of rice husk, Biores. Technol. 67 (1) (1999) 53-59, doi: http://dx.doi. org/10.1016/S0960-8524(99)00073-5.

13. C. Q. Dong, Z. B. Zhang, H. T. Liao, Q. Lu, Comparison of fast pyrolysis of poplar and pine woods on the basis of Py-GC-MS analysis, Chemistry and Industry of Forest Products 33 (6) (2013) 41-47 (in Chinese).

14. Y. P. Gao, The research on pyrolysis and weightlessness of several pines under different conditions, Fire Sci. Technol. 32 (11) (2013) 1196-1199 (in Chinese).

15. Y.-F. Liao, C.-C. Zeng, X.-Q. Ma, Thermogravimetric analysis of pyrolysis and combustion characteristics of typical biomass in south China, J. South China University of Technology (Natural Science Edition) 41 (8) (2013) 1-8 (in Chinese).

16. A.-Q. Fu, L.-J. Chen, J. Yang, Pyrolysis process and kinetics analysis of corn stalk and wheat straw, Chem. Ind. Eng. 26 (4) (2009) 350-353 (in Chinese)

17. J. J. M. Orfão, F. J. A. Antunes, J. L. Figueiredo, Pyrolysis kinetics of lignocellulosic materials - Three independent reactions model, Fuel 78 (1999) 349-358, doi: http://dx. doi.org/10.1016/S0016-2361(98)00156-2.

18. R. French, S. Czemik, Catalytic pyrolysis of biomass for biofuels production, Fuel Process. Technol. 91 (2010) 2532, doi: http://dx.doi.org/10.1016/j.fuproc.2009.08.011.

19. E. Jakab, E. M. Szacros, J. Borse, Effect of slight chemical modification on the pyrolysis behavior of cellulose fibers, J. Anal. Appl. Pyrol. 87 (2010) 117-123, doi: http://dx. doi.org/10.1016/j.jaap.2009.10.012.

20. P. Pan, C.-W. Hu, W.-Y. Yanga, Y.-S. Li, L.-L. Dong, L.-F. Zhu, D.-M. Tong, R.-W. Qing, Y. Fan, The direct pyrolysis and cat- 
alytic pyrolysis of Nannochloropsis sp. residue for renewable bio-oils, Biores. Technol. 1 (70) (2010) 4593-4599, doi: http://dx.doi.org/10.1016/j.biortech.2010.01.070.

21. P. R. Patwardhan, J. A. Satrio, R. C. Brown, R. C. Brown, $B$. H. Shanks, Influence of inorganic salts on the primary pyrolysis products of cellulose, Biores. Technol. 1 (112) (2010) 4646-4655, doi: http://dx.doi.org/10.1016/j.biortech.2010.01.112.

22. S. Tia, S. C. Bhattacharyat, P. Wibulswas, Thermogravimetric Analysis of Thai Lignite-Pyrolysis Kinetics, Energ.
Convers. 31 (3) (1991) 265-276, doi: http://dx.doi. org/10.1016/0196-8904(91)90080-3.

23. D. S. Thakur, H. E. Nuttall, Kinetics of pyrolysis Moroccan oil shale by thermogravimetry, Ind. Eng. Chem. Res. 26 (7) (1987) 1351-1356, doi: http://dx.doi.org/10.1021/ ie00067a015.

24. R. K. Agrawal, M. S. Sivasubramanian, Integral approximations for non-isothermal kinetics, AIChEJ. 33 (7) (1987) 1212-1214, doi: http://dx.doi.org/10.1002/ aic. 690330716 . 


\title{
SAŽETAK
}

\section{Pirolitičke karakteristike i kinetika ostataka stabla feniks kao potencijalne energije

\author{
Hua Li, ${ }^{*}$ Xu-Hui Li, Le Liu, Kun-Quan Li i Xiao-Hua Wang
}

\begin{abstract}
Upotrebom termogravimetrijskog analizatora pod argonskom atmosferom, ispitivani su proces pirolize i kinetički model pirolize ostataka stabla feniks (mala stabljika, velika stabljika i list) pri brzini zagrijavanja $30{ }^{\circ} \mathrm{C}$ min $^{-1} \mathrm{i}$ drvne smjese stabla feniks pri tri različite brzine zagrijavanja $\left(10{ }^{\circ} \mathrm{C} \mathrm{min}^{-1}, 30{ }^{\circ} \mathrm{C} \mathrm{min}^{-1}\right.$ i $\left.50{ }^{\circ} \mathrm{C} \mathrm{min}^{-1}\right)$. Katalizator i kopirolitički uzorci zagrijavani su brzinom od $30{ }^{\circ} \mathrm{C} \mathrm{min}-1$. Katalizatori su bili $\mathrm{Na}_{2} \mathrm{CO}_{3}, \mathrm{ZnCl}_{2}$ i CaO u masenom udjelu od $5 \%$. Eksperimentalni rezultati pokazali su da se proces pirolize ostataka stabla feniks sastoji od tri faze: dehidratacijska faza, glavna pirolitička faza i spora dekompozicija ostataka. Povećavanjem brzine zagrijavanja, pirolitičke karakteristike temperature stabla feniks rastu, javlja se pomak unatrag pirolitičke krivulje brzine, a brzina gubitka težine postupno se povećava. Energija aktivacije ostataka stabla feniks mijenja se kroz cjelokupni proces pirolize, a temperatura pirolize u rasponu tri glavne komponente (celuloze, hemiceluloze i lignina) postoji u fenomenu preklapanja. $U$ odnosu na malu stabljiku, srednju stabljiku i list, vjerojatnije je da će drvna smjesa stabla feniks biti pirolizirana pri istim brzinama zagrijavanja. Različiti katalizatori imaju drugačiji utjecaj na pirolizu. $\mathrm{ZnCl}_{2}$ pomiče početnu točku reakcije prema nižim temperaturama, ali ne ubrzava reakciju; $\mathrm{Na}_{2} \mathrm{CO}_{3}$ ubrzava reakciju bez promjene početne točke reakcije; $\mathrm{CaO}$ ubrzava reakciju i pomiče početnu točku reakcije prema višim temperaturama.
\end{abstract}

\section{Ključne riječi}

Ostaci stabla feniks, piroliza, termogravimetrijska analiza, kinetika, katalizatori 